\title{
Hydrocarbons Potential in the Azraq Area
}

\author{
Abdurrahman Qteishat, Mehaysen Ahmed AL-Mahasneh \\ Chemical Engineering Department, Al-Huson University Collage, Al-Balqa' Applied University, Irbid, Jordan \\ Email: qteishat6@yahoo.com,m.mahasneh@bau.edu.jo,mahsneh2008@hotmail.com
}

How to cite this paper: Qteishat, A. and AL-Mahasneh, M.A. (2018) Hydrocarbons Potential in the Azraq Area. Open Journal of Geology, 8, 753-763. https://doi.org/10.4236/ojg.2018.88044

Received: May 5, 2018

Accepted: August 1, 2018

Published: August 3, 2018

Copyright (C) 2018 by authors and Scientific Research Publishing Inc. This work is licensed under the Creative Commons Attribution-NonCommercial International License (CC BY-NC 4.0). http://creativecommons.org/licenses/by-nc/4.0/ cc) (i) (8) Open Access

\begin{abstract}
Azraq area occupied more than 1400 sq. $\mathrm{km}$ in the central part of Jordan. The stratigraphic sequences in the area consist of a lithological bedding of classic and carbonate rocks with representing good factors for oil generation and accumulation. Wadi Sir (WS-2) Sediments have geochemical characteristics of a typical source rocks for oil source rocks which are mature below $9843 \mathrm{ft}$, and carbonate rocks of Hummar, Shueb, and Wadi Sir-2 formation formations (Turonian Cenomanian age) are a reservoir rocks, where reservoirs are capped by shale and argillaceous limestone which is sufficiently thick to cap underlying reservoir. Twenty wells have been drilled in different blocks in the Azraq area, and oil of 32 API has been discovered in 1982, in the area, and starts natural flow production about $1500 \mathrm{bbl} /$ day from few wells, then production start decreasing due to lower reservoir pressure, then sucker rod pumps were used to produce oil. In this study, the regional maturity of the Wadi Sir-2 sediments appear that mature oil generation sources rocks occur within the northwesterly trending depression of the area where maturity of WS-2 sediments below $9843 \mathrm{ft}$ occurs, these mature source rocks amount to about $220 \mathrm{sq}$. km, based on average thickness of $108.27 \mathrm{ft}$ for WS- 2 sediments and extractable organic matter that was determined $3008 \mathrm{ppm}$. The volumetric method indicates that the total oil in place in the area is 480215 tons, taking a primary recovery factor of $12 \%$ then the total recoverable oil is 57,625 tons, while the cumulative oil producing is 53,137 tons.
\end{abstract}

\section{Keywords}

Fuluk Fault, Structure, Geochemical, Maturity, Kerogen, Hummar

Formations

\section{Introduction}

Azraq area is represented by a stratigraphic sequence ranging in age from Early Paleozoic to Late Pleistocene. The thickness of the upper Cretaceous-Lower Ter- 
tiary sediments decreases regionally from $800 \mathrm{~m}$ Wadi Al Mujb in the western part of Jordan to about $300 \mathrm{~m}$ in Maan-Ras Al Naqab eastward and and $150 \mathrm{~m}$ in Zakimat al Hasa, main increase in thickness in Maestrichtian-Danian-Paleocen age, which indicates a synsedementaty subsidence of separate basins within the neritic to littoral zones of deposition (Azraq-Wadi Sirhan basin, El-Jafr basin), in Oligocene time. East Jordan becomes separated in land areas and basins are shallowed with an accumulation of alternating marine and continental sediments. During Neogene time, in Azraq-Sirhan depression, calcareous and sandy marine deposits had developed. during Pleistocene time, the uplifted areas were locally covered with lacustrine and fluvial deposits. All quaternary deposits in Jordan are of continental origin [1].

Azraq area is originated due to long term subsidence epirogenic of the basin which may have started in Early Paleozoic time and continued to recent time. East Jordan has a regional gentle dip from the arch rim of Wadi Araba-Jordan graben towards the east, and from the escarpment of Ras El Naqab towards the northeast. The western part of the plateau is cut by an intense network of predominantly NNW to N, NW and EW trending faults. In the east, dips are gently towards the ENE Wadi Sirhan Depression. Geological surface mapping indicates that, the NW striking Wadi Sirhan depression and its NW extension. Azraq area represents an area of epirogenic subsidence without large scale faulting during the Cenozoic. Oil exploration shows that the sedimentary basin is divided into NW Azraq and SW Sirhan separated by an EW structural subsurface height. Synsedimentary faulting took place during latest upper Cretaceous. Greatest subsidence was in Azraq Sub-basin over 300 m (Cretaceous and Lower Tertiary marine sediments). There is [1] possibility of discovering hydrocarbons in the Azraq area.

The Yugoslav INA company had tested a few barrels of oil in the 1970s.

The reservoir is principally of Middle cretaceous carbonate, but may at time include thin sands [2].

\section{Location}

The Azraq area is a small fault dominated area which covers an area more than of 1400 sq. km, located in eastern Jordan and striking approximately northwest to southeast (Figure 1).

\section{Structural Area}

It is bounded from the north by the Basalt Plateau, from the east- northeast by Fuluk fault, from the west and northwest by Tertiary outcrops sediments, and from the south by Suwaqa fault. The surface elevation varies gently between 500 - 700 m.a.s.l, it slopes towards the south and southeast (Figure 2).

\section{Geological Column Section of Azraq Area}

Azraq area represents an interesting thick stratigraphic section which is composed primarily of carbonate, sandstone and shale sediments ranging in age 


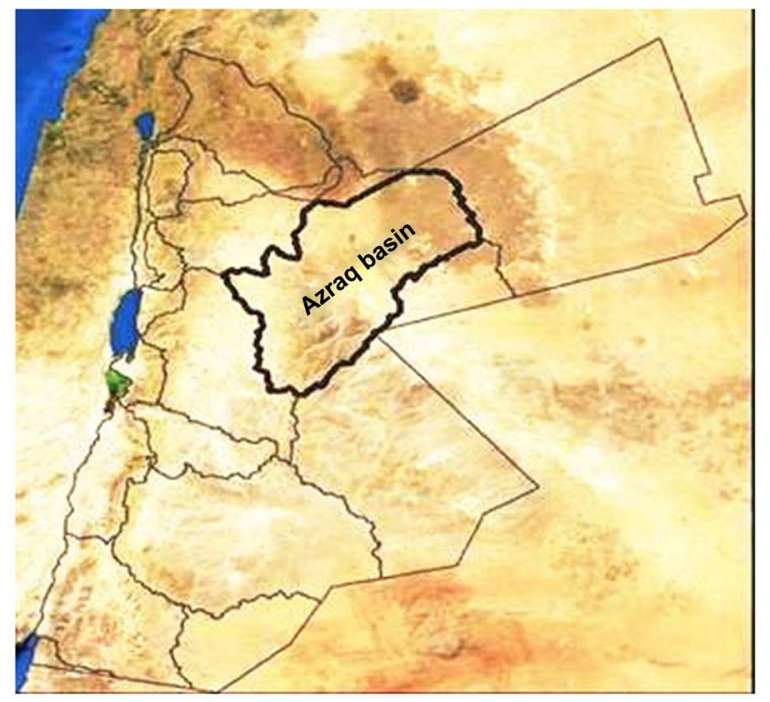

Figure 1. Location Map of Azraq area.

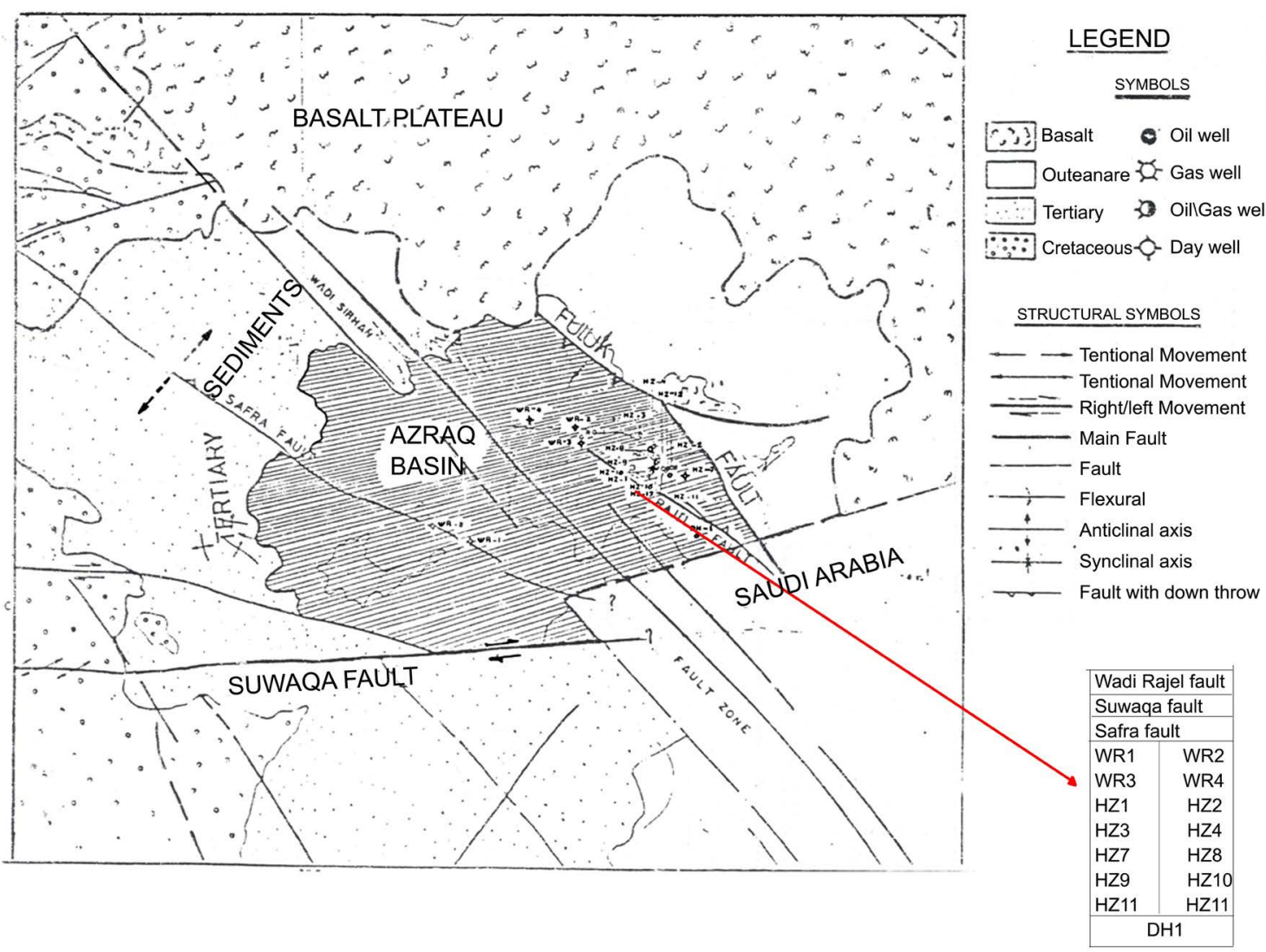

Figure 2. Structural area.

from Early Paleozoic to Late Paleocene with an average thickness in excess of 5500 meters, the major thickness reduction in the sequence appears towards the west-northwest direction, while remarkable increase in thickness is observed towards the east-southeast corner of the basin.

The stratigraphic sequence represents some major unconformities and/or 
non-conformity surface. The Cretaceous-Tertiary deposits in the basin comprise a thick sedimentary section measuring more than 3000 meters mostly of marine deposits were the lower Cretaceous boundary sandstone (Kurnub-Albian/Aptian) is marking transition zone on the major unconformity between the Jurassic and the Early Creataceous. Remarkable thickness changes in the Cretaceous section has also followed the same trend of Jurassic-Triassic thinning or pinch out towards west-northwest and this will support the idea of the continuous un-weighted subsidence of the Azraq area (Figure 3).

Remarkable thickness changes in the Cretaceous section has also followed the same trend of Jurassic-Triassic thinning or pinch out towards west-northwest and this will support the idea of the continuous un-weighted subsidence of the Azraq area (Figure 4).

\section{Structure of Reservoir}

Azraq area is originated due to long term subsidence epirogenic of the basin which have started in Early Paleozoic time and continued to recent time. The pronounced dip is towards southeast and east-northeast, i.e. dipping towards the Fuluk fault where during the Mesozoic renewed subsidence took place resulting in deposition of more than 3000 meters of marine Cretaceous and Tertiary sediments along the down thrown of the Fuluk fault.

Both compressional and tensional forces were in one way or another responsible for Azraq area configuration. Rejuvenation along fault plane is common. The Azraq area displayed a complex combined structural style which is comparatively difficult to study in detail to delineate structural traps of the basin (Figure 5, Figure 6).

\section{Discussion and Results}

\subsection{Geochemistry Chrematistics}

In general, the total organic content of such sediment which is eventually become source beds of petroleum ranges between $(0.5 \%$ and $5.0 \%)$ [4].

\begin{tabular}{|c|c|c|c|c|c|c|}
\hline AGE & LITHOLOGY & FORMATION & SOURCE & RES. & SEAL & PRODUCTION/SHOWS \\
\hline \multirow{2}{*}{ PLIOCENE } & $\widetilde{E}$ & $\begin{array}{l}\text { JORDAN VALLEY } \\
\text { GP. }\end{array}$ & & & & \multirow{13}{*}{$\begin{array}{l}\text { O AZRAQ AREA } \\
\text { O HAMZAH } \\
200 \text { BOPD - 25API } \\
\text { FROM } 4 \text { WELLS }\end{array}$} \\
\hline & $>$ & LISSAN SALT & & & & \\
\hline MIOCENE & 4 & $\begin{array}{l}\text { JORDAN VALLEY } \\
\text { GP. }\end{array}$ & & & & \\
\hline EOCENE & NI & SARA & & & & \\
\hline PALEOCENE & ביבובי & TAQIYEH & & & & \\
\hline \multirow{3}{*}{$\begin{array}{l}\text { MAEST. } \\
\text { CAMP.- } \\
\text { SANT. } \\
\text { TURON. }\end{array}$} & 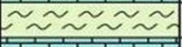 & GHAREB & & & & \\
\hline & 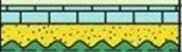 & $\begin{array}{l}\text { AMMAN } \\
\text { AZRAQ }\end{array}$ & & & & \\
\hline & 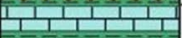 & WADI ESSIR & & & & \\
\hline 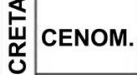 & 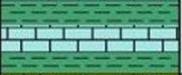 & $\begin{array}{c}\text { SHUEIB } \\
\text { HUMMAR } \\
\text { Fuhays Ma'ur }\end{array}$ & & & & \\
\hline ALBIAN & & KURNUB & & & & \\
\hline $\begin{array}{c}\text { MIDDLE } \\
\text { JURASSIC }\end{array}$ & 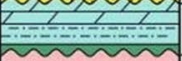 & HUNI & & & & \\
\hline TPInse & $\wedge \wedge \wedge \wedge \wedge$ & ABU RUWEIS & & & & \\
\hline IRIASDIC & $\begin{array}{lll}1 & 1 \\
1 & 1 & 1 \\
1 & 1\end{array}$ & MA'IN & & & & \\
\hline
\end{tabular}

Figure 3. Geological column section of Azraq area [3]. 


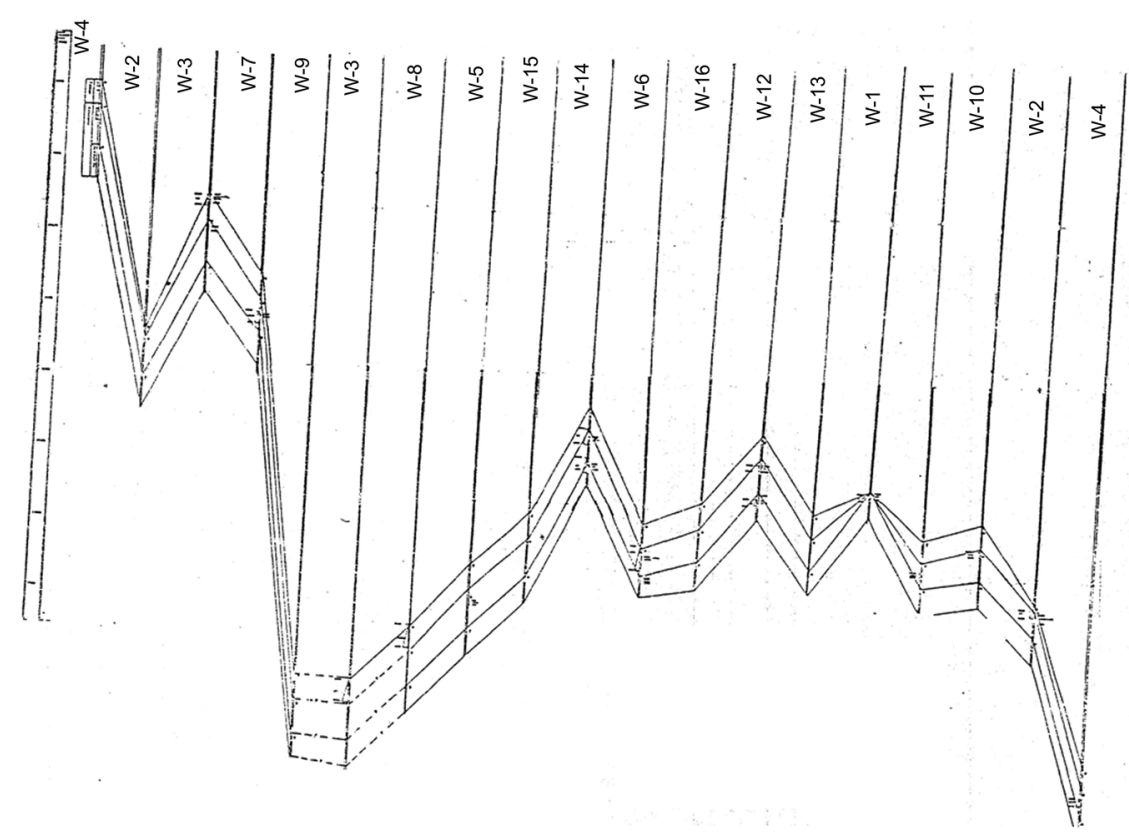

Figure 4. Structure Cross Sections of WS-2, Shueib and Hummar Formations.

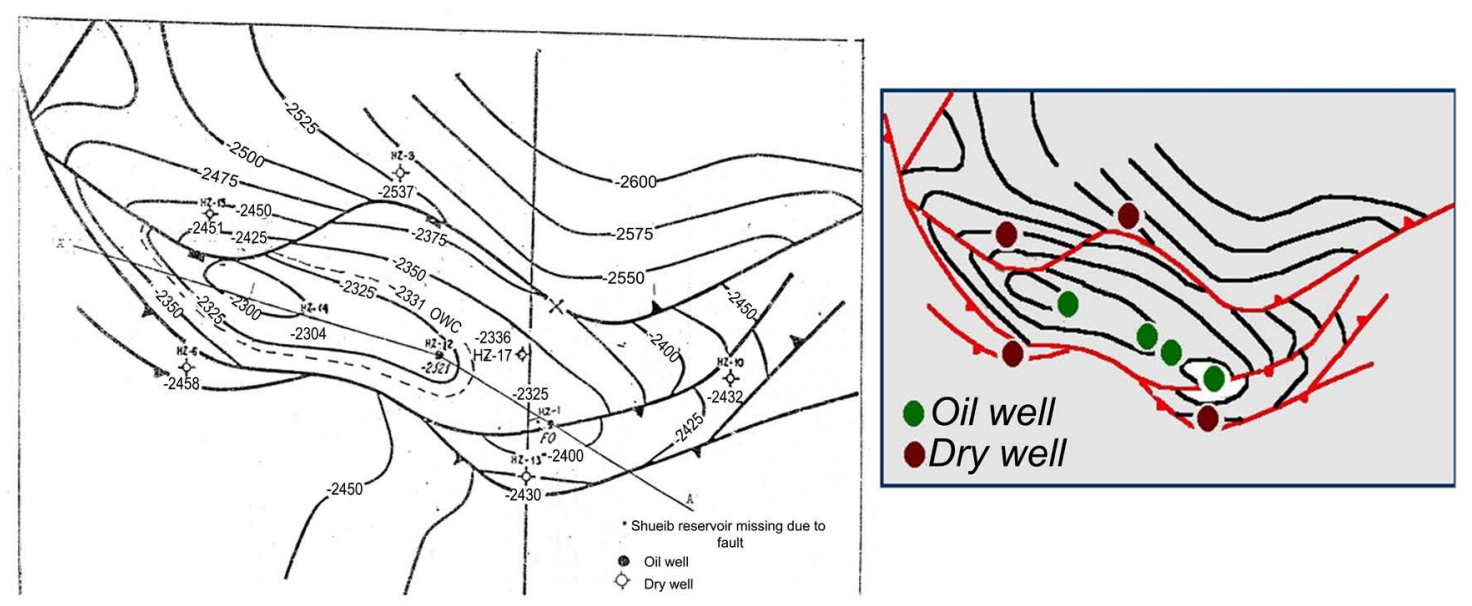

Figure 5. Structure map Top Shueib formation.

Table 1 shows the average vitrinite reflectance RO value obtained from well-3 for Wadi Sir Formation (WS-2 lower part) is $0.84 \%$, which is early mature. The correlation studies show that Wadi Sir formation is the major source for the Hamzeh area, and capable for oil generation according to the available geochemical data, Wadi Sir-2 formation of Turonian age (WS-2) which is approximately at depth $9842.52 \mathrm{ft}$ (located to the east, north and northeast of Hamzeh) has sufficient organic matter enabling the generation of oil, which fed Hamzeh structure which is structurally higher. The distribution of terpanes for Hamzeh oil and sediments from a mature sediments of WS-2 suggest that the (WS-2) is the source rock for oil in WS-2 (Turonian age) and Shueib and Hummar formations (Cenomanian age). Faults provided a pathway for oil migration from 
Table 1. Average RO\% values through different wells.

\begin{tabular}{ccccc}
\hline Age and formation & Well 1 & Well 2 & Well 3 & Well 4 \\
\hline Eocone (Sara formation) & & 0.63 & & \\
Paleocene (Taqiyeh formation ) & & 0.7 & \\
Maestrichtian (Ghareb formation) & 0.92 & & \\
Campanian/Santonian (Amman formation) & & 1.014 & & 0.203 \\
Turonian (Wadi Sir formation) & & 0.84 & 0.052 \\
Cenomanian (Shueib and hummer formation) & 0.63 & & 0.86 & 0.29 \\
Albian/aptian (Kurnub formation) & 0.41 & & & 0.3 \\
Jurassic (Huni formation) & & & & 0.47 \\
Triassic (Main formation) & 0.49 & & 0.53 \\
Ordovician (Unnamed) & 1.2 & &
\end{tabular}

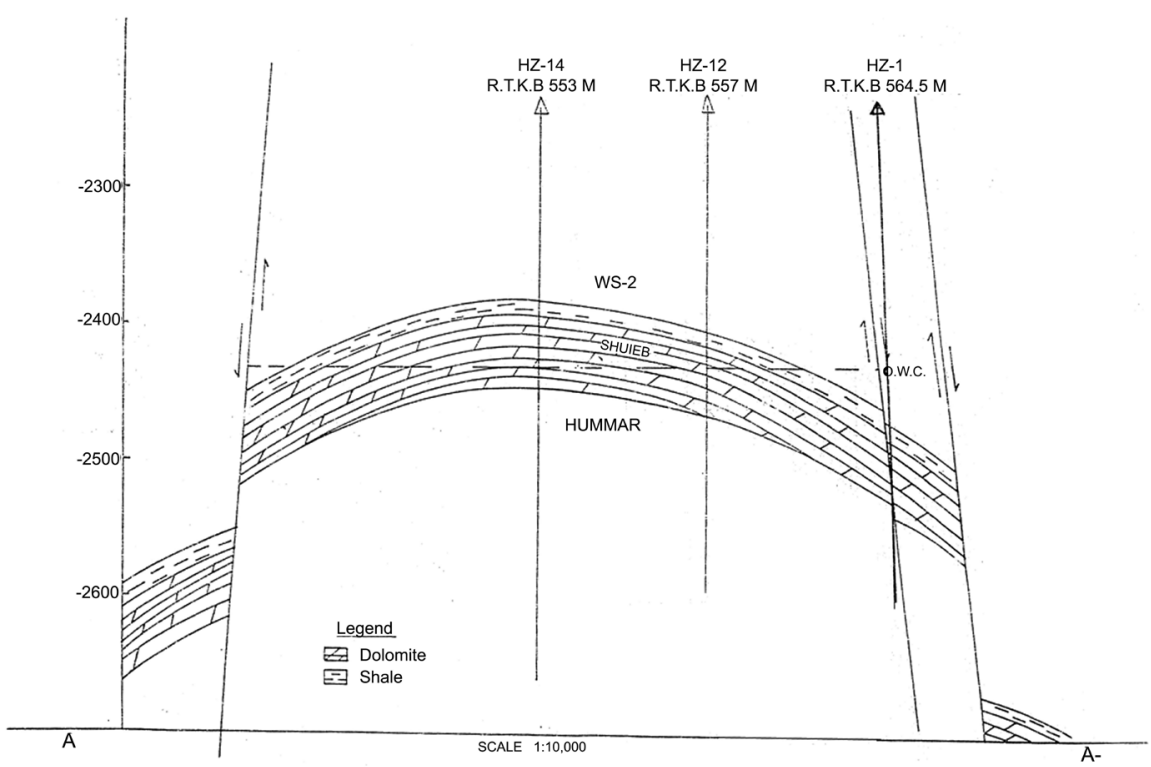

Figure 6. Longitudinal Geological profile Shueib Reservoir.

source rocks to the reservoir rocks. So WS-2 is considered as a source rocks in the deeper part of Azraq and as a reservoir rocks in higher Hamzeh strccture.

The Wadi-Sir sediments have many geochemical characteristics that are typical of crude oil source rock. Table 2 shows that the average TOC is $1.04 \%$ which indicates that it has good organic matter richness. TOC in WS- 2 member ranges between $(0.1 \%$ and $4.0 \%)$ which is a high organic content. The main important factor in the origin of petroleum is the thermal history of the source rocks, WS-2 source rocks are buried below $8202 \mathrm{ft}$. Figure 7 shows that the level of thermal evaluation of formation is sufficiently mature for oil generation, at this depth the temperature is $\left(75^{\circ} \mathrm{C}\right)$. Figure 8 shows that hydrogen and oxygen index values are an indication of oil prone organic rich sediments.

WS-2 source rocks are buried below $9843 \mathrm{ft}$. At this depth the temperature is 
Table 2. Average total organic content (TOC) values.

\begin{tabular}{|c|c|c|c|c|c|c|c|c|c|c|c|c|c|c|c|}
\hline Age & $\begin{array}{r}\text { Wel } \\
\text { format }\end{array}$ & $\begin{array}{l}11 \\
\text { tion }\end{array}$ & Well 1 & Well 2 & Well 3 & Well 4 & Well 5 & Well 6 & Well 7 & Well 8 & Well 9 & Well 10 & Well 11 & Well 12 & Well 13 \\
\hline \multirow{2}{*}{ Eaestrichtian } & \multirow{2}{*}{ Ghareb } & Upper & & & & 12.12 & 12.87 & & & & & & & & 0.93 \\
\hline & & Lower & & 0.08 & & & & & 0.30 & & & & & & \\
\hline \multirow{3}{*}{$\begin{array}{l}\text { Campanian/ } \\
\text { Santonian }\end{array}$} & \multirow{3}{*}{ Amman } & Upper & & & & & & 0.2 & & & & & & & \\
\hline & & Lower & 0.2 & & 0.2 & 0.5 & & 0.12 & & & & & 0.21 & & \\
\hline & & WS & 0.1 & 0.15 & 0.72 & 1.90 & 1.90 & 0.1 & & & & & 0.19 & 0.1 & \\
\hline \multirow{3}{*}{ Turonian } & \multirow{3}{*}{ Wadi Sir } & WS-1 & & 0.22 & 0.25 & 0.13 & & & 1.04 & 1.07 & & & 0.19 & 2.03 & \\
\hline & & $\mathrm{H}-2$ & 0.1 & 0.09 & 0.18 & 1.30 & 0.17 & & 0.15 & & & 0.88 & & & 0.2 \\
\hline & & WS-2 & & 1.21 & 1.49 & 1.00 & 1.80 & & 0.25 & & 0.68 & & & & \\
\hline \multirow[t]{4}{*}{ Cenomanian } & \multicolumn{2}{|c|}{ Shuieb } & 0.74 & 0.29 & 0.43 & 1.38 & & & & & 1.08 & & 0.23 & 0.23 & 0.77 \\
\hline & \multicolumn{2}{|c|}{ Hummer } & & & & 0.51 & & 0.24 & & & 0.43 & 0.21 & & 0.29 & 0.53 \\
\hline & \multicolumn{2}{|c|}{ Fuhies } & 0.2 & & & & & & & & & 1.11 & & & \\
\hline & \multicolumn{2}{|c|}{ Naur } & 0.07 & 0.38 & 0.2 & 0.3 & 0.06 & 0.26 & 0.06 & & 0.39 & 0.09 & & 0.64 & 0.12 \\
\hline Albian aptain & \multicolumn{2}{|c|}{ Kurnub } & & & 0.4 & 0.1 & 1.06 & 0.07 & 0.12 & & & & & 0.05 & \\
\hline Jurassic & \multicolumn{2}{|c|}{ Huni } & & & 1.32 & & & & & & & & & 0.81 & \\
\hline Triassic & \multicolumn{2}{|c|}{ Main } & & 0.13 & 0.3 & & 0.05 & 0.16 & & & & & & & \\
\hline Ordovician & \multicolumn{2}{|c|}{ Unnamed } & 0.91 & 0.83 & 0.76 & & & & & & & & & & \\
\hline Cambrian & \multicolumn{2}{|c|}{ Unnamed } & 0.21 & & & & & & & & & & & & \\
\hline
\end{tabular}

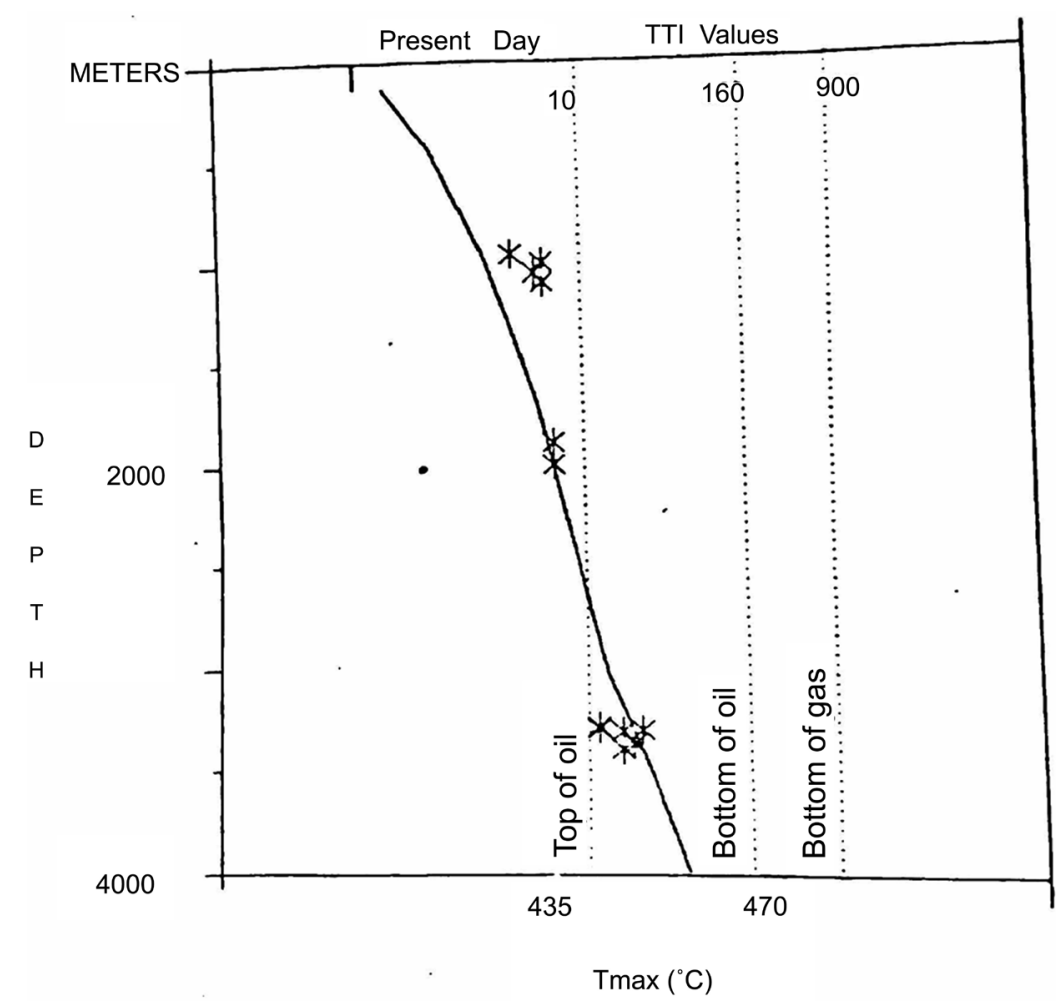

Figure 7. Maturity with depth. 


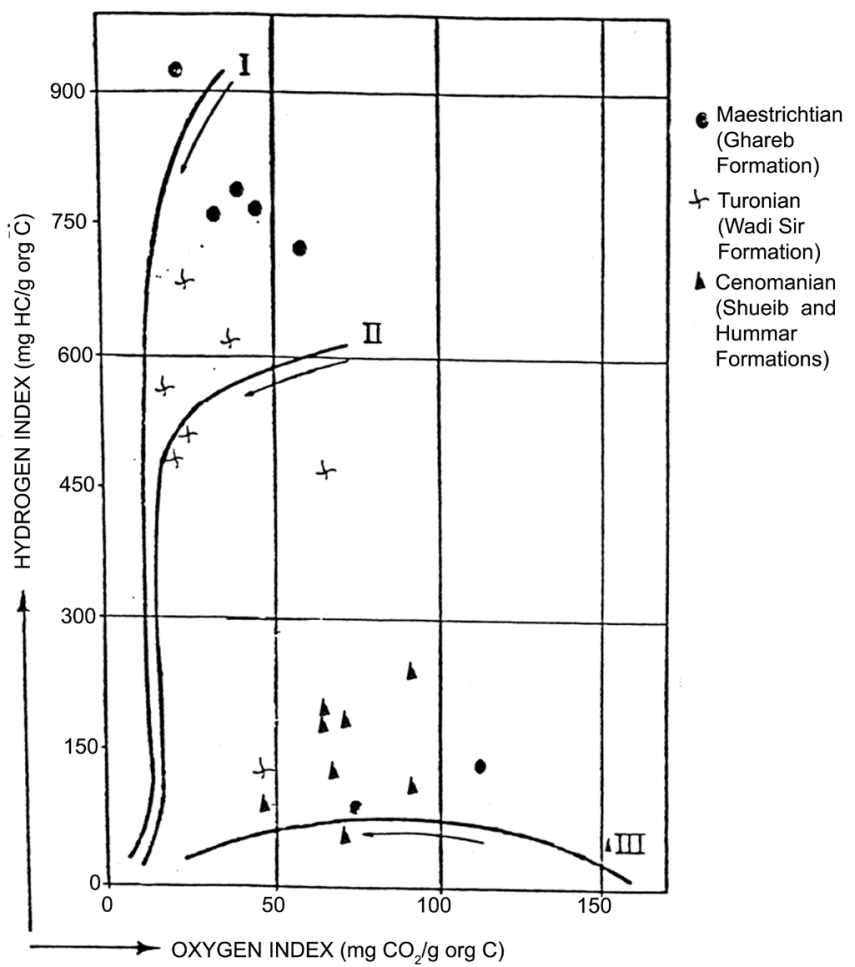

Figure 8. Evolution kerogen in petroleum formation, from Tissot, 1984, permession to publish by AAPG.

$194^{\circ} \mathrm{C}$ which is in the temperature range in the catagenes stage. Thickness of WS-2 member is $108.27 \mathrm{ft}$. Figure 8 shows that it consists of planktonic foraminiferal argillaceous sediments (mudstone/wackestone) and carbonates. The oil generated from this member is a type kerogen II cycloparaffins (nephthenes and aromatics), which are the fairly high original hydrocarbon content.

The regional maturity of the Wadi Sir-2 sediments (Figure 9) appears that mature oil generation sources rocks occur within the northwesterly trending depression bounded to the north by the Fuluk Fault, and to the south by the Rajil faulty, maturity sediments of WS-2 below $9843 \mathrm{ft}$ occur primarily to the southeast, north and northwest of Hamzeh area, and the area covered by these mature source rocks amounts to about $220 \mathrm{sq}$. km, based on average thickness of 108.27 $\mathrm{ft}$ for WS-2 sediments and extractable organic matter that was determined 3008 ppm. The total amount of oil generated is estimated at $59.4 \times 1,000,000$ tons. Assuming a trapping efficiency of $1 \%-2 \%$ due to the geological situation in the basin tectonic, maturation, migration, reservoir... etc. So $600 \times 1000-1200 \times$ 1000 tons of oil would be reserved and this value is higher than the total oil in place in Hamzeh oil field which has been calculated by volumetric methods (480,215 tons).

\subsection{Reservoir Rocks}

Carbonate rocks comprise the reservoir rocks in Azraq area (WS-2, Shueib, and Hummar). Figure 10 shows where this reservoir is separated from each other by 


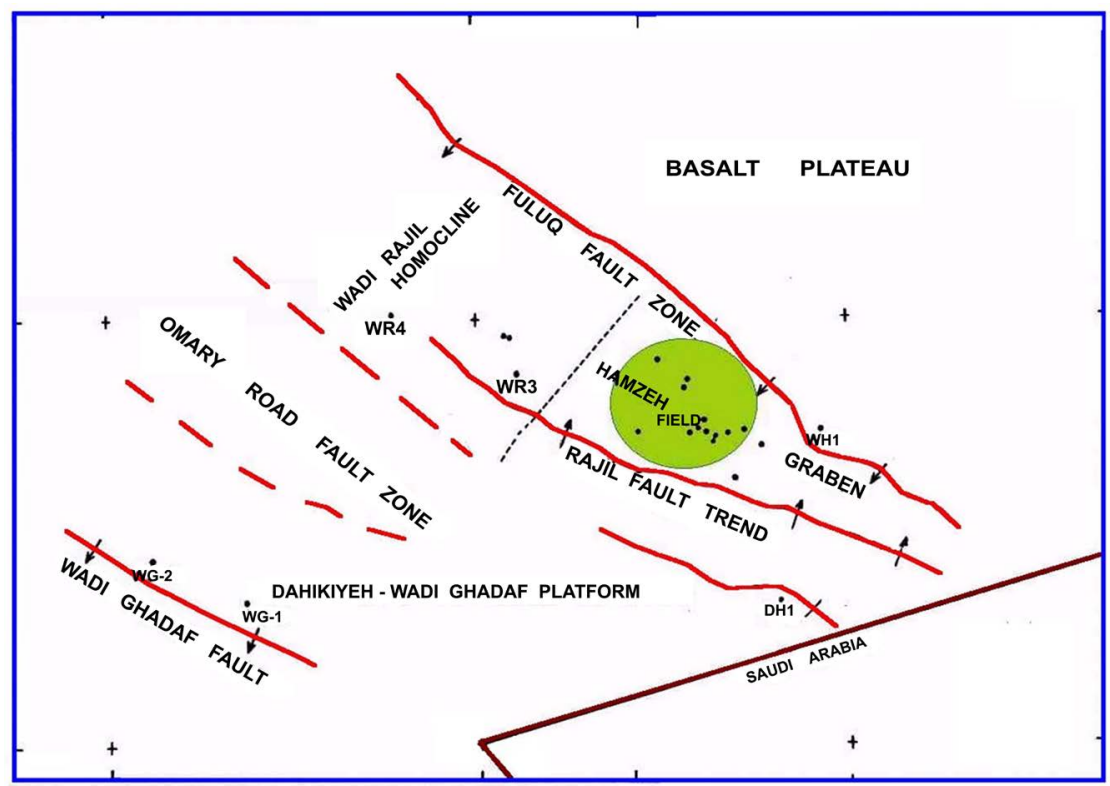

Figure 9. maturity map of Wadi Essir formation [5].
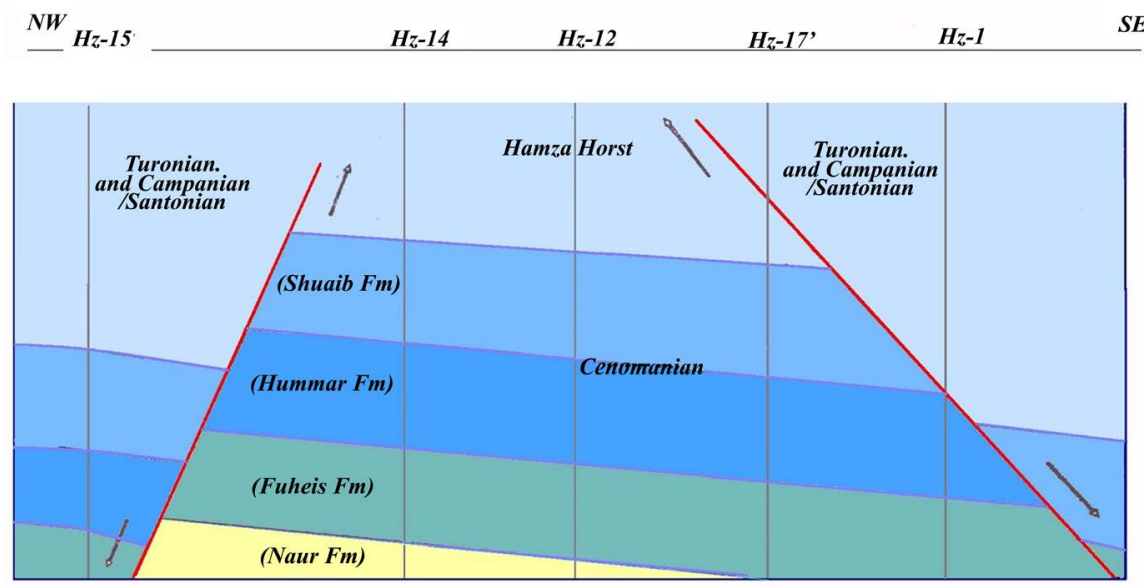

Figure 10. Geological cross sections for reservoir wells.

shale and argillaceous limestone. Azraq area has one oil field which is west northwest to east-southeast aligned anticlinal feature on an uplifted block intensely faulted and is flanked to the north and south by major strike slip fault. The type of reservoir is horst block. Three wells 1, 12 and 14 in Hamzeh area (out of 28 wells in Azraq area) are producing medium gravity crude oil with low GOR and sulpher content, from Shueib and Hummar reservoirs. These two reservoirs are of Cenomanian age, the younger Shueib is immediately underlain by the Hummar. Shueib reservoir has better reservoir rock properties due to its dolomitic facies. The producing reservoirs are depending on the degree of fractures and the fractures almost improved recovery from the low porosity matrix. In Wadi Sir (WS-2) reservoir (wells 3, 7) crude oil was recovered during D.S.T but chart interpretation showed a depletion behavior, where oil shows have been reported from Turonian-Cenomanian reservoirs in the remaining wells in the 
area. The average gross reservoir thickness is $108.27 \mathrm{ft}$ for WS-2, and $72.18 \mathrm{ft}$ for Shueib and $124.67 \mathrm{ft}$ for Hummar. Table 3 shows that the average net pay zone is $24.61 \mathrm{ft}$ for Shueib reservoir in well 12 and well 14 wells, and in well 1 (Shueib reservoir is missing due to fault), and 5 meters for Hummar reservoir in wells 1, 12 and 14.

The major type of porosity developed in WS-2, Shueib and Hummr reservoirs is primary interparticle, secondary skeletal moldoic, grain dissolution, secondary dolomitic intercrystalline and fracture porosities, where these porosities are of poor lateral continuity which indicates that the reservoir quality porosities development is localized, and it is believe that the fractures are enhanced the reservoir permeability.

\subsection{Traps}

The predominant type of hydrocarbon traps are structural with a complex fault controlled system of generally normal fault although numerous major unconformity surfaces are present throughout the stratigraphic column where the possibility of finding other types of traps is not excluded.

The oil trapped in Hamzeh structures originated from WS-2 source rock, where the sediments buried deeply below $9843 \mathrm{ft}$. Consequently, the oil in Hamzeh structures most likely migrated from the north or east and the migration may have occurred laterally along the porous beds and vertically along the fault planes during the Eocene time.

Table 3. Thickness reservoir interval.

\begin{tabular}{cccc}
\hline Reservoir Well & WS-2 & Shueib & Hummer \\
\hline Well 1 & $*$ & $*$ & 37.5 \\
Well 2 & $*$ & 23 & 38 \\
Well 3 & 93 & 17.5 & 37 \\
Well 4 & 34.5 & 26 & 39.5 \\
Well 5 & 33.5 & 24 & 35.5 \\
Well 6 & 33.5 & 27 & 39 \\
Well 7 & 35 & 24,5 & 40 \\
Well 8 & 37.5 & 27 & 38 \\
Well 9 & 33 & 24 & 37 \\
Well 10 & 31.5 & 19 & 37.5 \\
Well 11 & 32.5 & 27 & 48 \\
Well 12 & 33 & 23.5 & 33.5 \\
Well 13 & 27.5 & 20 & 32 \\
Well 14 & $*$ & 30 & 45 \\
Well 15 & 36 & 29 & 38.5 \\
Well 16 & 33 & 33 & 45 \\
\hline
\end{tabular}

${ }^{\star}$ Missing due to fault. 
The distribution of seal rocks in Azraq area play an important role in the localization of oil in the reservoirs, where carbonate reservoirs are capped by shale and argillaceous limestone which are sufficiently thick to cap underlying reservoir. It is possible that the rims of dip together with minor faulting also could create vertical seas as these minor faults may have lead to juxtaposition of marginal reservoir against very tight stratigraphic units based on their magnitude and throw.

\subsection{Oil in Place}

The volumetric method indicates that the total oil in place in Hamzeh field is 48,0215 tons taking a primary recovery factor of $12 \%$ then the total recoverable oil is 57,625 tons, while the cumulative oil producing till July 1989 was 53137 tons with natural flow.

Due to the relationship between potential source rocks and reserves with other elements, besides storage capacity of the reservoirs, it is hardly to expect a remarkable result of hydrocarbon discoveries. It would be recommended to prepare a feasibility study before any further exploration activities in the area.

\section{Conclusions}

1) The regional maturity of WS-2 Sediments appears that mature oil generation sources rocks occur within the northwestly trending depressing bounded to the north by Fuluk fault, and to the south by the Rajil faulty.

2) In the deepest part of the Azraq area, sufficient maturation has been achieved for the generation of oil.

3) The distribution of seal rocks in Azraq area plays an important role in the localization of oil in the reservoirs, where carbonate reservoirs are capped by shale and argillaceous limestone which are sufficiently thick to cap underlying reservoir.

\section{References}

[1] Bender, F. (1974) Geology of Jordan. Gebrüder Borntraeger, Berlin, Stuttgart.

[2] Beydoun, Z.R. (1988) The Middle East: Regional Geology and Petroleum Resources. Scientific Press, Beaconsfield.

[3] Al-Rawi, D.M.M. (2014) Petroleum Systems in Jordan. GEO ExPro, 11, No. 1.

[4] Tissot, B.P. and Welte, D.H. (1978) Petroleum Formation and Occurrence. Springer Verlag, Berlin, Heidelberg, New York.

[5] Middle East Geological Forum Company, Exploration Petroleum. 